\title{
Cationic Oligo(thiophene ethynylene) with Broad-Spectrum and High Antibacterial Efficiency under White Light and Specific Biocidal Activity against $S$. aureus in Dark
}

Qi Zhao, Junting Li, Xiaoqian Zhang, Zhengping Li and Yanli Tang ${ }^{*}$

Key Laboratory of Applied Surface and Colloid Chemistry, Ministry of Education, Key

Laboratory of Analytical Chemistry for Life Science of Shaanxi Province, School of Chemistry and Chemical Engineering, Shaanxi Normal University, Xi'an 710062, People's Republic of China.

* E-mail: yltang@ snnu.edu.cn (Prof. Y. L. Tang) 


\section{Supporting Information}

\section{Contents}

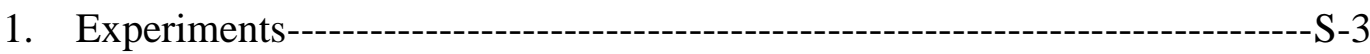

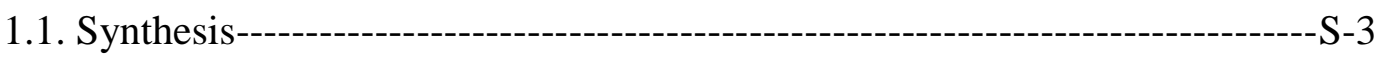

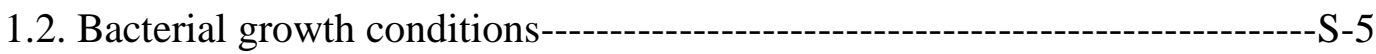

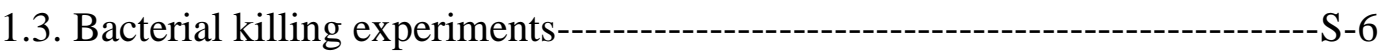

1.4. Reactive oxygen species (ROS) measurements------------------------------S-7

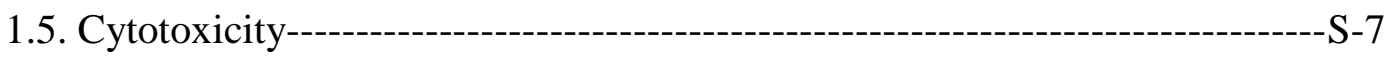

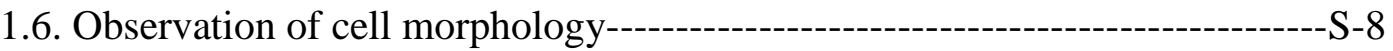

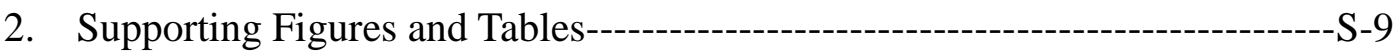

Reference---------------------------------------------------------------------------------------S-11 


\section{Experiments}

\subsection{Synthesis}

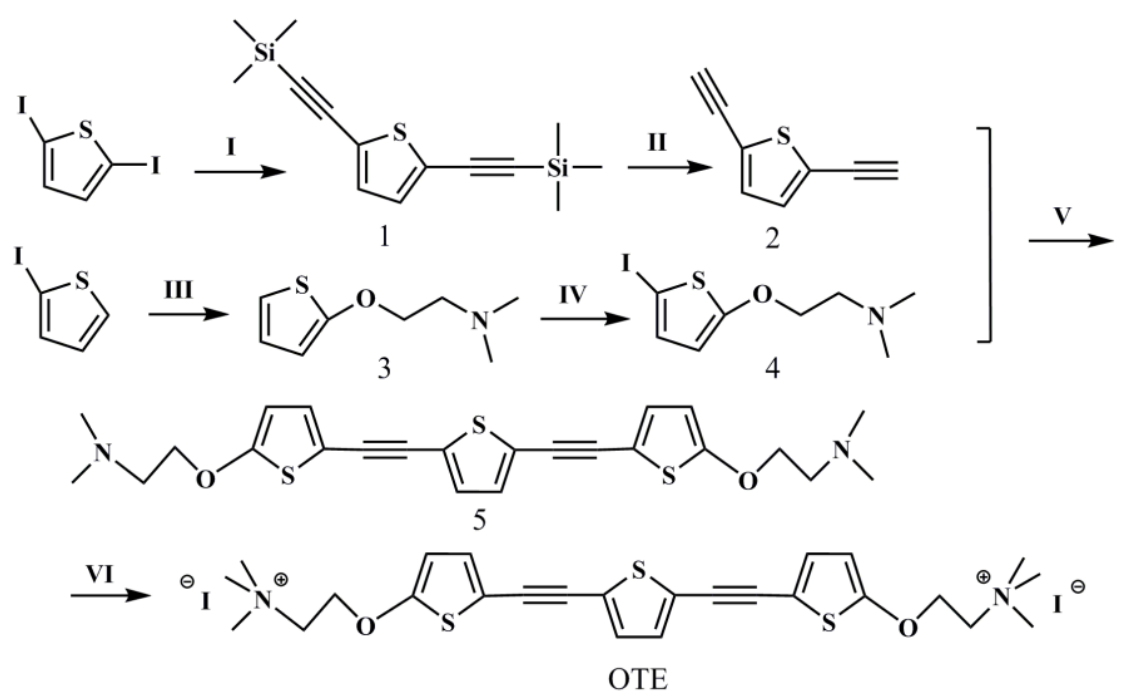

Scheme S1. Synthesis of OTE: (I) $\mathrm{Pd}\left(\mathrm{PPh}_{3}\right)_{2} \mathrm{Cl}_{2} / \mathrm{CuI}$, diethylamine/CHCl 3 , r. t. 5 h; (II) $\mathrm{K}_{2} \mathrm{CO}_{3}, \mathrm{MeOH} / \mathrm{THF}$, r. t. 5 h; (III) Cu, DMAP, NaH, DMF, $75^{\circ} \mathrm{C}$, overnight; (IV) NIS, $\mathrm{CH}_{2} \mathrm{Cl}_{2} / \mathrm{AcOH}$, r. t. 4 h; (V) $\mathrm{Pd}\left(\mathrm{PPh}_{3}\right)_{2} \mathrm{Cl}_{2} / \mathrm{CuI}$, diethylamine/CHCl 3 , r. t. 24 h; (VI) $\mathrm{CH}_{3} \mathrm{I}, \mathrm{CHCl}_{3}$, r. t. overnight.

Compound 1 and compound 2 were synthesized according to the literature. ${ }^{1}$

Compound 3. Under nitrogen atmosphere, $\mathrm{NaH}(360 \mathrm{mg}, 15 \mathrm{mmol})$ was added slowly to the solution of $\mathrm{N}, \mathrm{N}$-dimethylethanolamine $(1.5 \mathrm{ml}, 15 \mathrm{mmol})$ in DMF (30 $\mathrm{mL}$ ) in the ice bath, the resulting solution was vigorously stirred for $30 \mathrm{~min}$. Then, 2-iodothiophene ( $1 \mathrm{~mL}, 10 \mathrm{mmol})$ was drowsily added to the mixture. After adding of $\mathrm{Cu}(64 \mathrm{mg}, 1 \mathrm{mmol})$ and DMAP (105 $\mathrm{mg}, 0.86 \mathrm{mmol})$, the mixture was heated to $75{ }^{\circ} \mathrm{C}$ overnight. The cooled solution was treated with methanol to remove excess $\mathrm{NaH}$ and the solid was removed through filtration. The filtrate was extracted with 
DCM. Then the collected organic phase was washed with brine and water, dried over $\mathrm{MgSO}_{4}$ and concentrated in vacuum. The residue was chromatographed on silica gel using DCM/methanol (v/v=50/1) to give compound 3 (602 mg, 35\%) as brown liquid. ${ }^{1} \mathrm{H}$ NMR $\left(300 \mathrm{MHz}, \mathrm{CDCl}_{3}\right) \delta 7.16(\mathrm{q}, J=6.0 \mathrm{~Hz}, 1 \mathrm{H}), 6.79(\mathrm{~d}, J=6.0 \mathrm{~Hz}, 1 \mathrm{H}), 6.25$ $(\mathrm{d}, J=6.0 \mathrm{~Hz}, 1 \mathrm{H}), 4.05(\mathrm{t}, J=6.0 \mathrm{~Hz}, 2 \mathrm{H}), 2.72(\mathrm{t}, J=6.0 \mathrm{~Hz}, 2 \mathrm{H}), 2.33(\mathrm{~s}, 6 \mathrm{H}) .{ }^{13} \mathrm{C}$ NMR $\left(75 \mathrm{MHz}, \mathrm{CDCl}_{3}\right) \delta 157.73,124.57,119.63,97.28,68.07,58.24,45.80$. HRMS (ESI): m/z: $172.0791\left([\mathrm{M}+\mathrm{H}]^{+}\right)$.

Compound 4. NIS (545 mg, $2.4 \mathrm{mmol}$ ) was added in three portions over a period of $1.5 \mathrm{~h}$ to the solution of Compound $3(276 \mathrm{mg}, 1.6 \mathrm{mmol})$ in $\mathrm{DCM}$ and $\mathrm{AcOH}(8$ $\mathrm{ml}, 1: 1)$ at $0{ }^{\circ} \mathrm{C}$. Then, the mixture was warmed to room temperature and the reaction was stirred for $3 \mathrm{~h}$. Water $(3 \mathrm{ml})$ was added to the reaction mixture and the acid was neutralized with a saturated solution of $\mathrm{NaHCO}_{3}$. The mixture was extracted with DCM, the combined organic layer organic phase was washed with brine and water, dried over $\mathrm{MgSO}_{4}$ and concentrated in vacuum. The residue was chromatographed on silica gel using DCM/methanol (v/v=100/1, 0.5\% triethylamine) to give compound 4 (415 mg, 87\%) as yellow solid. ${ }^{1} \mathrm{H}$ NMR (300 MHz, $\left.\mathrm{CDCl}_{3}\right) \delta 7.47(\mathrm{~d}, J=6.0 \mathrm{~Hz}$, $1 \mathrm{H}), 6.73(\mathrm{~d}, J=6.0 \mathrm{~Hz}, 1 \mathrm{H}), 4.49(\mathrm{t}, J=6.0 \mathrm{~Hz}, 2 \mathrm{H}), 3.36(\mathrm{t}, J=6.0 \mathrm{~Hz}, 2 \mathrm{H}), 2.88(\mathrm{~s}$, $6 \mathrm{H}) .{ }^{13} \mathrm{C} \mathrm{NMR}\left(75 \mathrm{MHz}, \mathrm{CDCl}_{3}\right) \delta 130.88,116.87,66.17,56.77,46.55$. HRMS (ESI): $\mathrm{m} / \mathrm{z}: 297.9758\left([\mathrm{M}+\mathrm{H}]^{+}\right)$.

Compound 5. Under nitrogen atmosphere, Compound 4 (595 mg, 2 mmol) was dissolved completely in degassed diethylamine and $\mathrm{CHCl}_{3}(24 \mathrm{~mL}, 1: 2)$. Compound 2 (132 mg, $1 \mathrm{mmol}), \mathrm{Pd}\left(\mathrm{PPh}_{3}\right)_{2} \mathrm{Cl}_{2}(70.2 \mathrm{mg}, 0.1 \mathrm{mmol})$ and $\mathrm{CuI}(38.1 \mathrm{mg} .0 .2 \mathrm{mmol})$ 
then were added to the solution. The resulting mixture was stirred at room temperature for $24 \mathrm{~h}$ under nitrogen atmosphere. The solution was extracted with $\mathrm{CH}_{2} \mathrm{Cl}_{2}$. The collected organic phase was washed with brine and water, dried over $\mathrm{MgSO}_{4}$ and concentrated in vacuum. The residue was chromatographed on silica gel using $\mathrm{CH}_{2} \mathrm{Cl}_{2} /$ methanol (v/v=100/1, with $0.5 \%$ triethylamine) to give compound 5 (58 mg, 12\%) as yellow solid. ${ }^{1} \mathrm{H}$ NMR $\left(300 \mathrm{MHz}, \mathrm{CDCl}_{3}\right) \delta 7.19(\mathrm{~d}, J=6.0 \mathrm{~Hz}, 2 \mathrm{H})$, $7.08(\mathrm{~d}, J=6.0 \mathrm{~Hz}, 2 \mathrm{H}), 6.76(\mathrm{~d}, J=6.0 \mathrm{~Hz}, 2 \mathrm{H}), 4.42(\mathrm{t}, J=6.0 \mathrm{~Hz}, 4 \mathrm{H}), 2.92(\mathrm{t}, J=$

$6.0 \mathrm{~Hz}, 4 \mathrm{H}), 2.51(\mathrm{~s}, 12 \mathrm{H}) .{ }^{13} \mathrm{C} \mathrm{NMR}\left(75 \mathrm{MHz}, \mathrm{CDCl}_{3}\right) \delta 159.18,134.56,131.58$, 127.34, 126.23, 122.92, 117.18, 88.28, 86.08, 67.86, 57.25, 44.64. HRMS (ESI): m/z: $471.1227\left([\mathrm{M}+\mathrm{H}]^{+}\right)$.

OTE. (24 mg, $0.051 \mathrm{mmol})$ was dissolved in $\mathrm{CHCl}_{3}(10 \mathrm{~mL})$ and the reaction mixture was stirred vigorously to form a homogeneous solution. Then, $\mathrm{CH}_{3} \mathrm{I}$ ( $213 \mathrm{mg}$, $1.53 \mathrm{mmol}$ ) was added and the mixture was stirred at room temperature overnight. The solid was collected by filtration, washed with $\mathrm{CHCl}_{3}$ for three times and dried under vacuum to give OTE (30 mg, 88\%) as brown solid. ${ }^{1} \mathrm{H}$ NMR (300 MHz, DMSO- $\left.d_{6}\right) \delta 7.72(\mathrm{~d}, J=6.0 \mathrm{~Hz}, 2 \mathrm{H}), 7.59(\mathrm{~d}, J=6.0 \mathrm{~Hz}, 2 \mathrm{H}), 7.38(\mathrm{~d}, J=6.0 \mathrm{~Hz}$, $2 \mathrm{H}), 4.65(\mathrm{~b}, 4 \mathrm{H}), 3.81(\mathrm{~b}, 4 \mathrm{H}), 3.22(\mathrm{~s}, 18 \mathrm{H}),{ }^{13} \mathrm{C}$ NMR $\left(75 \mathrm{MHz}, \mathrm{DMSO}-d_{6}\right) \delta$ $160.64,136.48,132.50,131.50,129.08,128.63,117.62,87.34,78.25,65.00,52.02$, 44.52. HRMS (ESI): m/z: $250.0813\left([\mathrm{M}-2 \mathrm{I}]^{2+}\right)$.

\subsection{Bacterial growth conditions}

Gram-positive bacteria (S. aureus, S. epidermidis) and Gram-negative bacteria (E. 
coli, R. solanacearum) were chosen for this study. Bacterial samples were transferred from the frozen state onto agar slants $(1.8 \%$ agar + triphenyl tetrazolium chloride medium (TTC)) for R. solanacearum, 1.2\% agar + Lysogeny Broth (LB) for E. coli, $1.5 \%$ agar + Nutrient Broth (NB) for S. epidermidis and 1.2\% agar + brain heart infusion (BHI) for S. aureus) incubated at $37{ }^{\circ} \mathrm{C}$ overnight and then held at $4{ }^{\circ} \mathrm{C}$ for up to 2 weeks. A single colony from the slants was incubated in $50 \mathrm{~mL}$ of $\mathrm{NB}(R$. solanacearum) for $18 \mathrm{~h}$ with shaking at $30{ }^{\circ} \mathrm{C}$. The culture for E. coli, S. epidermidis, S. aureus is LB, NB and BHI, respectively, and the incubation was kept overnight with shaking at $37{ }^{\circ} \mathrm{C}$. After growth, the bacterial culture was centrifuged at $2000 \mathrm{rpm}$ for $20 \mathrm{~min}$ (R. solanacearum) or $6000 \mathrm{rpm}(S$. aureus, S. epidermidis and E. coli) for 2 min at $4{ }^{\circ} \mathrm{C}$ and the pellet was suspended in $0.9 \% \mathrm{NaCl}$ solution. This washing procedure was repeated twice. The final concentration of bacteria was around $2 \times 10^{7} / \mathrm{mL}$.

\subsection{Bacterial killing experiments}

The antibacterial activities of EO-OPE-1(Th), EO-OPE-1(C3) and OTE were determined by incubation with bacterial cells suspensions for $10 \mathrm{~min}$ in the dark at room temperature. Then the mixture solutions were exposed to $90 \mathrm{~mW} / \mathrm{cm}^{2}$ white light for 30 or $60 \mathrm{~min}$, or incubated in the dark for 30 or $60 \mathrm{~min}$. After bacteria were incubated with the oligomers in the light or dark, a 1:1 ratio of dyes were added to the samples and kept in the dark for 15 min. The used bacteria stains were SYTO 9 (green

fluorescence) for Gram-negative bacteria, SYTO 24 (green fluorescence) for 
Gram-positive bacteria and propidium iodide (PI, red fluorescence). The final concentrations of SYTO 9, SYTO 24 and PI were $1.25 \mu \mathrm{M}, 0.25 \mu \mathrm{M}$ and $7.5 \mu \mathrm{M}$ respectively. Finally, the bacteria were examined using an Accuri C6 flow cytometry and Olympus IX73 fluorescence microscope.

\subsection{Reactive oxygen species (ROS) measurements}

In the experiments, $1.0 \mathrm{~mL}$ of the activated DCFH solution $(40 \mu \mathrm{M})$ was added EO-OPE-1(Th), EO-OPE-1(C3) and OTE (final concentration is $1.0 \mu \mathrm{M}$ ). The fluorescence spectra were measured after the specimens were irradiated under white light $\left(5 \mathrm{~mW} \cdot \mathrm{cm}^{-2}\right)$ for $5 \mathrm{~min}$. Fluorescence spectra of DCF solution was recorded in 500-700 nm emission range with the excitation wavelength of $488 \mathrm{~nm}$.

\subsection{Cytotoxicity}

The cytotoxicity of OTE in the dark was evaluated by MTT assay with HeLa cells. HeLa cells were seeded into a 96-well plate at a density of $1.0 \times 10^{4}$ cells per well in 100 of Dulbecco's Modified Eagle's Medium (DMEM) supplemented with 10\% fetal bovine serum and incubated for $24 \mathrm{~h}$ at $37{ }^{\circ} \mathrm{C}$ in $5 \% \mathrm{CO}_{2}$. The solution of OTE was diluted with DMEM to obtain predetermined concentrations (10, 30, 60, 90, 120, 500 and $1200 \mathrm{ng} / \mathrm{mL}$ ) of OTE. The medium in the well was then replaced with the solution of OTE $(200 \mu \mathrm{L})$ and the cells were incubated for $24 \mathrm{~h}$ and $48 \mathrm{~h}$ in the dark to evaluate the cytotoxicity. A $100 \mu \mathrm{L}$ aliquot of MTT was then added into each well after removing the solution of OTE and incubated for a further $4 \mathrm{~h}$. Finally, $100 \mu \mathrm{L}$ of DMSO were added to each well to dissolve the formazan crystals. The plate was kept 
at $37^{\circ} \mathrm{C}$ for $30 \mathrm{~min}$ and then the optical density (OD) was read on a microplate reader at $595 \mathrm{~nm}$ (OD595). The cells without OTE were used as a control and their cell viability was set at $100 \%$. Each sample was tested in six replicates per plate.

\subsection{Observation of cell morphology}

$2 \mathrm{~mL}$ of bacterial suspension $\left(\sim 10^{9}\right.$ colony forming units $\left.(\mathrm{CFU}) / \mathrm{mL}\right)$ was mixed with OTE followed by incubation under visible light irradiation or in the dark for $1 \mathrm{~h}$. The mixture of bacteria cells and OTE was centrifuged at $5000 \mathrm{rpm}$ for 5 minutes. The cell pellets were resuspended with $2.5 \%$ glutaraldehyde and incubated at $4{ }^{\circ} \mathrm{C}$ overnight, followed by washing with $0.01 \mathrm{M}$ PBS buffer for three times. Then, the fixed cells were dehydrated by sequential treatment with increasing concentrations of ethanol for $20 \mathrm{~min}$ at $4{ }^{\circ} \mathrm{C}$ and dehydrated with absolute ethanol twice. The dehydrated samples were resuspended with tert-butanol and transferred into freezing dryer (ALPHA1-2, CHRIST). The totally dried samples were sputter-coated with 10 nm thick gold/palladium. Morphologies of the bacterial cells were observed by SEM (Quanta 200, FEI). 


\section{Supporting Figures and Tables}

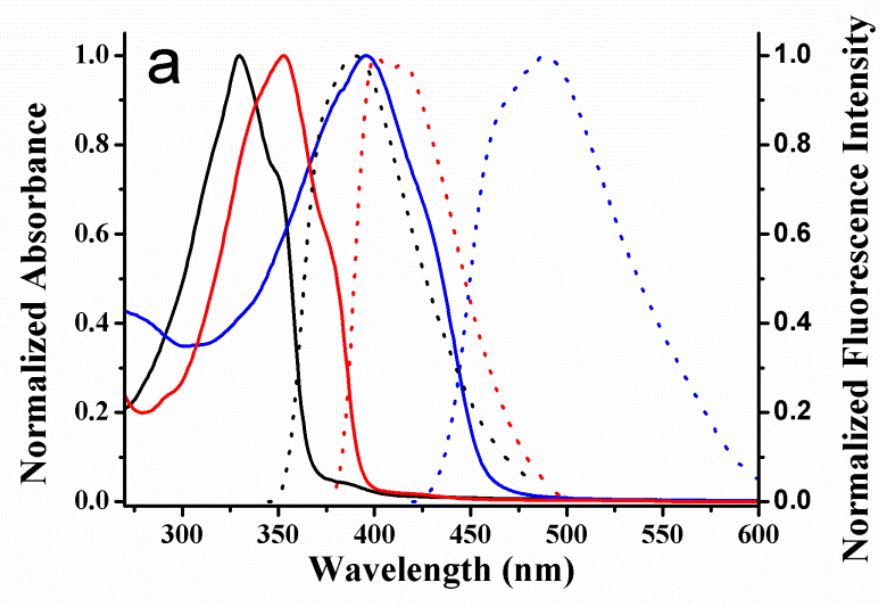

b

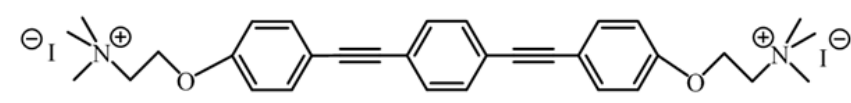

EO-OPE-1(C3)

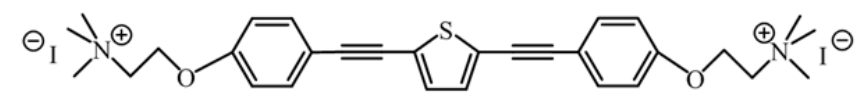

EO-OPE-1(Th)

Figure S1. (a) Absorption and fluorescence spectra of OTE (blue), EO-OPE-1(C3) (black) and EO-OPE-1(Th) (red) in water. Solid lines indicate absorbance spectra and dot lines indicate fluorescence spectra. (b) The structure of EO-OPE-1(C3) and EO-OPE-1(Th). 


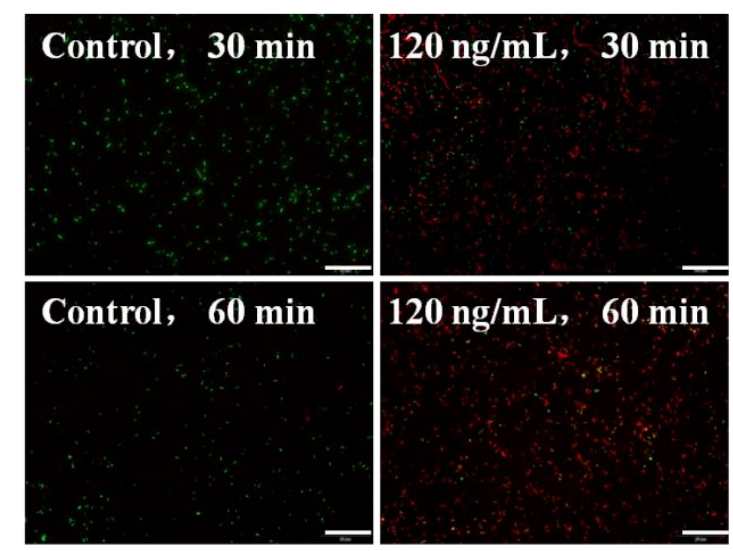

R. Solanacearum
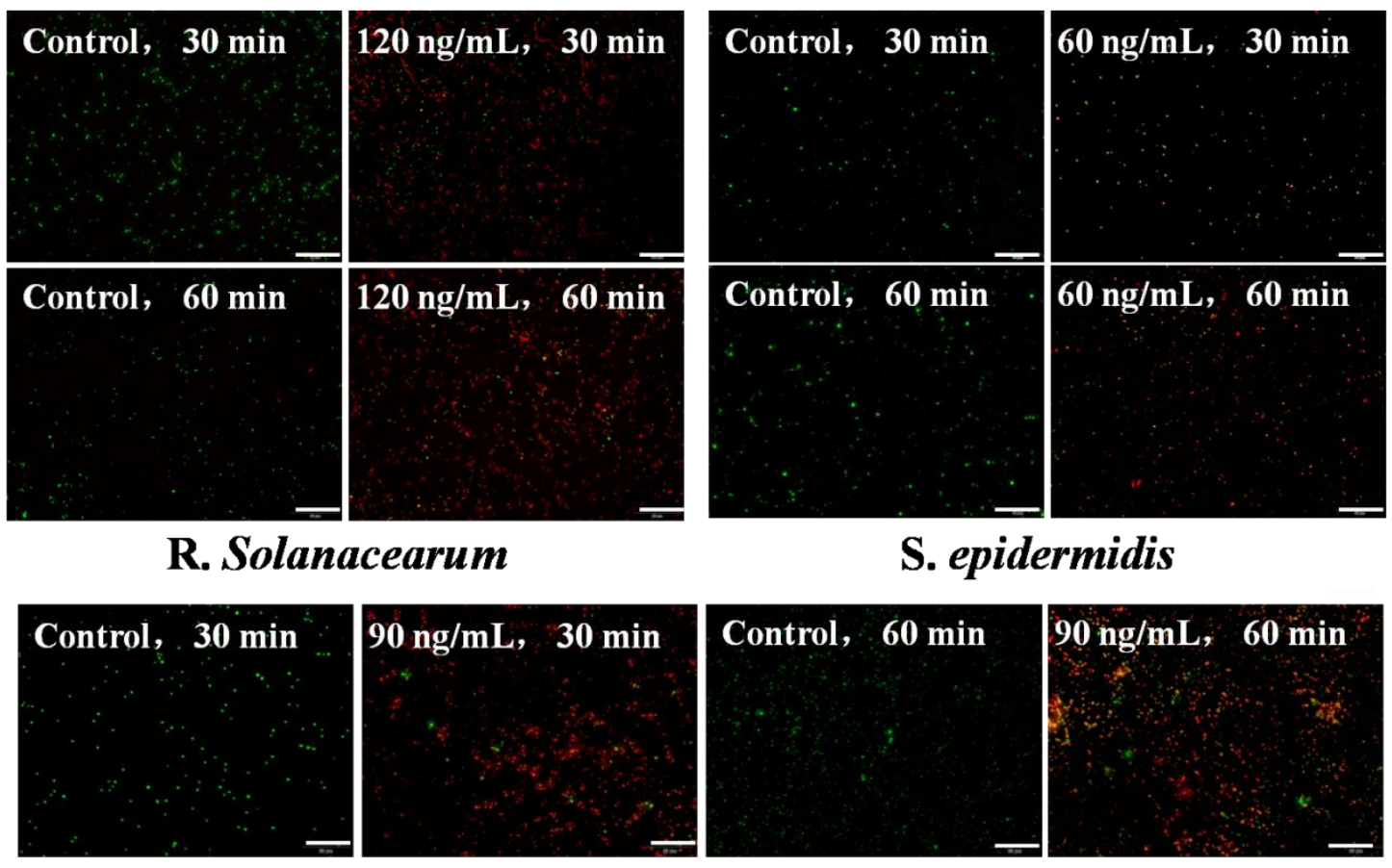

S. epidermidis
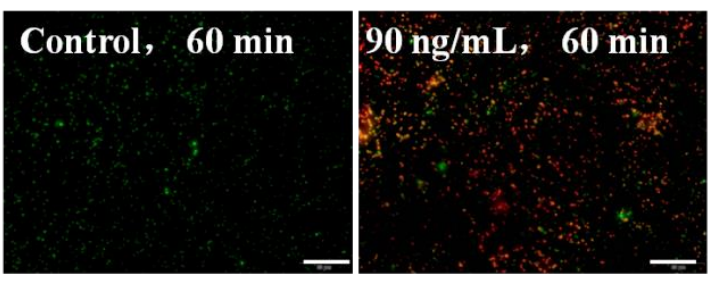

\section{E. coli}

Figure S2. Fluorescence microscope images of OTE with $R$. solanacearum, E. coli and S. epidermidis after 30 and 60 min of irradiation with visible light. Green staining indicates live bacteria and red staining indicates dead bacteria. Scale bar, $50 \mu \mathrm{m}$.
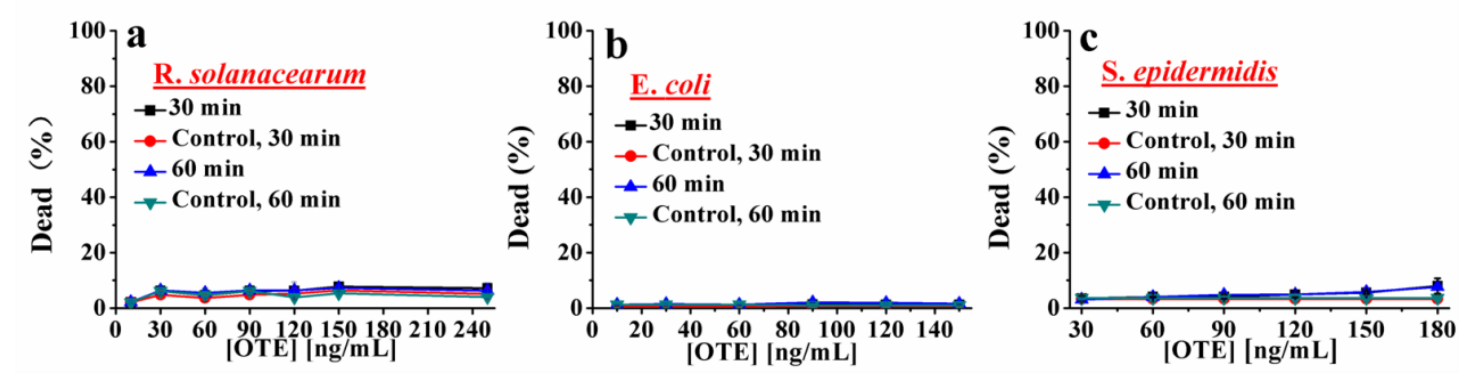

Figure S3. $R$. solanacearum (a), E. coli (b) and S. epidermidis (c) viabilities against OTE at various concentrations for 30 and $60 \mathrm{~min}$ in the dark. The error bars represent the standard deviations of three parallel measurements. 
Table S1. The half inhibitory concentrations $\left(\mathrm{IC}_{50}\right)$ of $R$. solanacearum, E. coli, $S$. aureus and S. epidermidis upon exposure to visible light.

\begin{tabular}{|c|c|c|}
\hline \multirow{2}{*}{ Strains } & \multicolumn{2}{|c|}{ Half Inhibitory Concentrations $\left(\mathrm{IC}_{50}\right)(\mathrm{ng} / \mathrm{mL})$} \\
\hline & $30 \mathrm{~min}$ & $60 \mathrm{~min}$ \\
\hline S. aureus & 8 & 7 \\
\hline S. epidermidis & 13 & 10 \\
\hline E. coli & 24 & 17 \\
\hline R. solanacearum & 52 & 28 \\
\hline
\end{tabular}

\section{Reference:}

1. Zhou, Z. J.; Corbitt, T. S.; Parthasarathy, A.; Tang, Y. L.; Ista, L. F.; Schanze, K. S.; Whitten, D. G.,

"End-Only" Functionalized Oligo(phenylene ethynylene)s: Synthesis, Photophysical and Biocidal Activity. J. Phys. Chem. Lett. 2010, 1, 3207-3212. 